\title{
PENDIDIKAN KARAKTER DAN PERKEMBANGAN PSIKOLOGI ANAK DALAM DONGENG BURUNG MERPATI DAN SEMUT MERAH
}

\author{
Mauliya Nandra Arif Fani \\ Institut Agama Islam Negeri Purwokerto \\ mauliya.nandra@gmail.com
}

\begin{abstract}
This study aims to describe the values of character education in the tale "The Pigeon and The Red Ant" that is concerned with child psychology development. This study is qualitative study using descriptive method. This study focus to character in tale "“The Pigeon and The Red Ant" that is concerned with child psychology development in the first their growth age. The social values as help each other, care, creative, and response to phenomenon of around that is found in this tale can create good personality for children in develpment of their psychology.
\end{abstract}

Keywords: Character Education, Child Psichology Development.

\begin{abstract}
Abstrak
Penelitian ini bertujuan untuk menjabarkan nilai-nilai pendidikan karakter dalam dongeng "Burung Merpati dan Semut Merah" kaitannya dengan pengajaran karakter dan perkembangan psikologi anak. Penelitian ini merupakan penelitian kualitatif dengan metode deskriptif. Penelitian ini memfokuskan karakter pada dongeng anak yang berjudul "Burung Merpati dan Semut Merah" yang dikaitkan dengan perkembangan psikologi anak di awal masa pertumbuhannya. Nilai-nilai sosial seperti tolong menolong, peduli, kreatif, dan tanggap terhadap fenomena sekitar yang ditemukan pada dongeng tersebut dapat menciptakan kepribadian baik bagi anak dalam perkembangan psikologinya.
\end{abstract}

Kata Kunci: Pendidikan Karakter, Perkembangan Psikologi Anak.

\section{Pendahuluan}

Pendidikan merupakan cara terbesar negeri ini untuk dapat mengembangkan sumber daya manusia yang akan menentukan kemajuan dan kemakmuran bersama. Tanpa pendidikan, dan apabila kebodohan masih merajai, maka tidak ada bedanya dengan bangsa ini pada zaman penjajahan kolonial lalu. Untuk itu, agar bangsa ini dikenal di dalam masyarakat dunia mempunyai martabat yang tinggi, kehormatan yang tidak untuk ditindas, maka semua rakyat harus berpendidikan, tanpa terkecuali. Pendidikan 
merupakan hak setiap warga negara, sesuai Undang-Undang Dasar 1945 pasal 31 ayat (1) . Begitu juga apabila ditinjau dari hadits Rasulullah, bahwa kita, seluruh umat manusia dituntut untuk mencari ilmu, bahkan sampai ke liang lahat. Kita belajar tanpa memandang usia dan tidak ada kata terlambat. Dalam sistem pendidikan yang baik, tentu akan memunculkan karakter yang baik dan setiap orang yang terlibat di dalamnya akan memiliki kepribadian yang baik pula. Karakter yang baik ini yang akan membawa bangsa Indonesia menjadi berstatus sosial tinggi di mata dunia. Indonesia akan disegani oleh negara lain dan akan mendapat pengakuan untuk menjadi negara yang kuat, kokoh, tanpa adanya perpecahan.

Akhir-akhir ini, sering dijumpai kasus yang menimpa anak usia di bawah umur tentang bullying, kekerasan, dan pelecehan. Bahkan tidak jarang pelakunya sendiri adalah sesama anak usia di bawah umur. Di media sosial, sering beredar kasus kekerasan terhadap anak oleh orang tuanya sendiri. Kasus pembullyan sesama anak di bawah umur yang sempat membuat ramai media sosial, juga perlu mendapat perhatian terhadap pendidikan yang berkembang di negara ini. Uraian tersebut menunjukkan bahwa karakter anak bangsa mengalami kemerosotan yang jauh dibanding generasi sebelumnya, di mana anak pada zaman tersebut memiliki karakter yang kuat untuk menjadi manusia yang unggul. Contohnya adalah sikap seorang siswa yang sangat segan dan menghormati gurunya. Di masa sekarang, tidak sedikit anak yang dengan gurunya memiliki hubungan yang sangat dekat, bahkan seperti kepada temannya sendiri. Karena hubungannya yang terlalu dekat, kewibawaan seorang guru kadang menjadi berkurang. Tedapat hal baiknya, yaitu guru menjadi lebih dekat dengan siswa dan mengetahui lebih jauh karakter siswa untuk menjadi seperti apa ke depannya. Akan tetapi, sisi negatif dari permasalahan tersebut adalah siswa menjadi tidak memahami sikap yang baik terhadap gurunya. Mereka seolah-olah tidak mengetahui perbedaan hubungannya antara dengan temannya sendiri dan dengan gurunya.

Sejak zaman dahulu, Indonesia dikenal dengan adat budayanya yang kental. Beragamnya budaya tersebut menjadikan Indonesia sebagai bangsa yang ramah di mata dunia. Sopan dan santun telah menjadi kebiasaan yang telah diwariskan turun menurun. Begitu juga dengan kebiasaan orang tua yang memperdengarkan dongeng kepada anaknya sebelum tidur. Hal ini sangat bagus dilakukan karena sesaat sebelum tidur, menurut Kurnia Widhiatuti yang disampaikan dalam Seminar Parenting, adalah kerja alam bawah sadar untuk menangkap informasi yang selanjutnya merangsang jiwa untuk melekatkan informasi tersebut. 
Dengan demikian, dongeng yang telah diperdengarkan sebelum tidur pada anak akan merangsang anak untuk menerapkan nilai-nilai dan karakter yang baik dari tokoh yang ada. Mereka mungkin akan memiliki tokoh idola dalam dongeng dan mengimajinasikan bahwa mereka turut serta dalam dongeng tersebut. Mereka akan menceritakannya kepada teman atau kerabatnya, sehingga keberanian untuk berbicara akan terbentuk. Sikap sosial dan kepeduliannya juga tercipta. Daya kreativitasnya untuk mengarang dongeng baru menjadi terlatih.

Perilaku seorang anak, terlebih di dalam pertumbuhannya pada masa kanak-kanak awal, sangat dipengaruhi oleh keadaan jiwanya. Pada masa ini, anak-anak akan meniru dan melakukan apapun yang ia lihat dari lingkungannya. Ketika senang, ia akan mengekspresikannya sesuai dengan yang telah didapat dari lingkungannya. Ketika sedih pun demikian. Untuk itu, peran orang tua menjadi hal yang vital untuk menjadi contoh yang baik. Adanya tontonan yang baik akan mempengaruhi keadaan jiwanya yang baik pula. Dengan demikian, hal-hal yang baik ini akan membentuk kepribadiannya sehingga membentuk karakter yang baik. Salah satu tontonan yang dapat membentuk karakter yang baik ini adalah dongeng. Melalui alur yang mudah dipahami, bahasa yang sesuai dengan umur mereka, dan disertai dengan gambar yang menarik, dongeng menjadi pilihan yang tepat untuk menanamkan karakter pada anak. Mereka yang mudah meniru apa yang didapat dari lingkungan sekitarnya, dengan diperdengarkan sebuah dongeng, maka melalui karakter tokoh dalam dongeng tersebut, anak akan dengan mudah meniru karakter yang baik dari tokoh tersebut. Anak akan diperkenalkan moral melalui imajinasi dari penggambaran cerita pada dongeng.

Dalam hal ini, tentu ada hambatan yang terjadi. Kesibukkan orang tua yang akhirnya tidak dapat menyempatkan membacakan dongeng untuk anaknya, menjadi salah satu penghambat. Bahkan, tidak jarang orang tua tidak memiliki waktu yang cukup untuk sekedar menemani anaknya bermain. Apabila hal tersebut telah terjadi, maka anak tidak mempunyai acuan untuk bersikap di dalam kehidupannya. Mereka hanya meniru apapun yang dilihat di lingkungan sekitarnya, tanpa mengetahui baik dan buruknya perbuatan tersebut. Begitu juga dengan anak, tidak dapat mencurahkan segala pikiran dan perasaannya kepada orang tua. Tidak ada waktu antara anak dengan orang tua untuk berkomunikasi, sehingga waktu yang seharusnya digunakan bersama orang tua, oleh anak digunakan untuk menonton televisi yang tanpa pengawasan dan 
kemungkinan besar memperlihatkan tindakan, percakapan, ataupun halhal lain yang tidak sesuai dengan umurnya.

\section{Metode Penelitian}

Dalam penelitian ini, metode yang digunakan adalah metode penelitian kualitatif. Penelitian kualitatif menurut Imam Gunawan adalah jenis penelitian yang temuan-temuannya tidak diperoleh melalui prosedur statistik atau bentuk hitungan lainnya. Metode ini lebih berdasarkan pada sifat fenomenologis yang mengutamakan penghayatan. Penelitian jenis ini bertujuan untuk mengembangkan konsep sensitivitas pada masalah yang dihadapi, menerangkan realitas yang berkaitan dengan penelusuran teori dari bawah dan mengembangkan pemahaman akan satu atau lebih dari fenomena yang dihadapi. Data yang dihasilkan dari metode penelitian ini umunya bersifat kualitatif seperti perilaku, persepsi, motivasi, dan secara deskriptif dalam bentuk kata-kata dan bahasa pada suatu konteks khusus yang alamiah dan dengan memanfaatkan berbagai metode ilmiah.

Pendekatan yang digunakan dalam penelitian ini adalah pendekatan kualitatif deskriptif, yaitu mendeskripsikan data untuk mendapatkan kesimpulan terhadap sesuatu yang diteliti secara umum, sesuai dengan permasalahanyangakanditeliti ${ }^{1}$. Alatyangdigunakan untuk mengumpulkan hasil penelitian ini adalah peneliti itu sendiri. Teknik pengumpulan data ini dilakukan dengan studi pustaka, dengan cara melakukan observasi pada buku-buku yang tersedia di perpustakaan yang kemudian disimpulkan sendiri sehingga membentuk kalimat yang mendukung pembuatan jurnal ilmiah ini.

\section{Pembahasan}

\section{A. Pendidikan Karakter}

Pendidikan karakter dapat dibentuk dengan cara memberikan bacaan dongeng setiap hari kepada anak. Pendidikan adalah setiap usaha yang dilakukan untuk memajukan kehidupan manusia. Menurut Kamus Besar Bahasa Indonesia, pendidikan adalah proses pengubahan sikap dan tata laku seseorang atau kelompok orang dalam usaha mendewasakan manusia melalui upaya pengajaran dan pelatihan, atau dapat disebut sebagai proses, cara, dan perbuatan mendidik. Sedangkan karakter adalah sebuah tindakan yang dihasilkan seseorang dari keadaan jiwanya secara spontan yang membentuk kebiasaan dan yang membedakan seseorang 
dengan orang lain. Jadi, pendidikan karakter adalah semua perbuatan atau semua usaha dari generasi tua untuk mengalihkan nilai-nilai serta melimpahkan pengetahuan, pengalaman, kecakapan, serta keterampilan kepada generasi selanjutnya sebagai usaha untuk menyiapkan mereka agar dapat memenuhi fungsi hidup mereka, baik jasmani, begitu pula rohani ${ }^{2}$. Oleh karena itu, pendidikan karakter mengusahakan semua anak untuk damat memiliki kualitas hidup yang baik. Pendidikan ini mengajarkan anak bahwa kehidupan akan mudah dilalui dengan bekal karakter yang baik. Selama ada dongeng dalam masa kecil anak, maka masa tersebut sangat berarti bagi tumbuh kembang anak. Karakter yang disampaikan melelui dongeng tersebut menjadi contoh kepada anak untuk bersikap secara unggul.

Sedangkan menurut Ki Hajar Dewantara, pendidikan karakter adalah tuntutan segala kekuatan kodrat yang ada pada anak agar mereka kelak menjadi manusia dan anggota masyarakat yang dapat mencapai keselamatan dan kebahagiaan yang setinggi-tingginya ${ }^{3}$. Dalam hal ini, tentu pendidikan karakter merupakan anugerah yang diberikan Tuhan kepada manusia agar mereka dapat menjalani kehidupan dengan penuh kebahagiaan. Maka, manusia perlu mengembangkan pendidikan yang telah diberikan tersebut. Tugas manusia adalah memaksimalkan potensi yang ada sehingga dapat menjadi pribadi yang berbudi luhur. Sedangkan istilah karakter adalah sifat-sifat kejiwaan, akhlak, atau budi pekerti yang membedakan seseorang dari yang lain ${ }^{4}$. Setiap orang mempunyai karakter yang berbeda. Oleh karena itu, baik maupun buruknya seseorang dapat ditentukan dari karakternya yang ditunjukkan dalam perilaku sehari-hari. Karena perilaku tersebut dilakukan tanpa disadari, yang menunjukkan perbuatan yang spontan, maka karakter sangat tepat untuk mengetahui kepribadian seseorang dan menentukan apakah sikapnya baik atau tidak.

Menurut Agus Wibowo, pendidikan karakter adalah pendidikan yang menanamkan dan mengembangkan karakter-karakter luhur kepada anak didik sehingga mereka memiliki karakter luhur tersebut, menerapkan, dan mempraktikan dalam kehidupannya, entah dalam keluarga, sebagai anggota masyarakat dan warga negara ${ }^{5}$. Bangsa Indonesia yang dikenal memiliki tingkat ramah-tamah yang tinggi harus dilestarikan sampai generasi seterusnya, sehingga moral bangsa tetap terjaga dan tidak mudah dipengaruhi budaya luar yang tidak sesuai dengan kepribadian luhur bangsa Indonesia sejak zaman dahulu. Indonesia tetap bermoral yang baik, karakter baik yang kuat, dan unggul dalam budi pekerti. Sering dijumpai pepatah "lebih baik jadi orang penting, tetapi lebih penting jadi orang baik". 
Sesuai kalimat tersebut, berkarakter baik lebih diutamakan dibanding memiliki tugas yang begitu penting, entah itu dalam pemerintahan, dalam kepegawaian, atau di manapun itu tetapi tidak memiliki sikap jujur dalam menjalani tugas yang penting tersebut. Bukan hanya merugikan orang lain, apabila itu terjadi, orang yang bersangkutan juga ternilai telah berbuat dosa, dan akan ditanggung di hari yang lebih kekal kelak. Ajaran agama pun mengajarkan bahwa adab lebih penting dan berarti daripada ilmu. Orang yang beradap tetapi kurang ilmunya akan lebih dihargai daripada orang yang berilmu tetapi tidak mempunyai adab yang baik dalam sikap sehari-harinya.

\section{B. Pentingnya Pendidikan Karakter}

Menurut Lickona, pendidikan bagi anak dalam membentuk karakter dan moral yang baik agar efektif dilakukan di lingkungan keluarga dan sekolahnya ${ }^{6}$. Keluarga adalah tempat mendidik anak yang paling dasar dan yang paling utama dilakukan. Oleh keluarga, anak diajari sopan dan santun dalam bersikap dan bersosialisasi dengan lingkungan sekitarnya. Tidak hanya hubungannya dengan sesama manusia, tetapi kepada sesama makhluk. Seorang anak yang kurang mendapat perhatian dari keluarganya sejak kecil, akan sangat berbeda perilakunya dibanding mereka yang mendapat perhatian keluarganya. Anak yang dengan kekurangannya tersebut akan cenderung lebih kasar dan bertindak tanpa dipikirkan terlebih dahulu. Anak-anak seperti ini biasanya akan tumbuh menjadi pribadi yang bebas, dan apabila berteman dengan anak yang demikian pula akan membentuk kelompok geng di kalangannya. Mereka biasanya melakukan tindakan yang seharusnya tidak boleh dilakukan di umurannya, seperti berkelahi, berkata kasar, bertindak tidak sopan bahkan terhadap orang yang lebih tua atau gurunya, dan lain-lain. Akan tetapi, tidak semua anak dengan keadaan yang sama memiliki perlaku yang sama. Sikap anak akan berkembang seiring dengan bertambahnya usia. Dan perkembangan sikap setiap anak berbeda, tergantung kapan ia memulai masa dewasanya. Tidak jarang anak yang berusia lebih tinggi memiliki sikap kedewasaan yang lebih rendah dibanding anak yang usianya jauh lebih rendah.

Selain di lingkungan keluarga, pendidikan karakter efektif dilakukan di sekolahnya. Untuk kalangan kanak-kanak, dongeng menjadi pilihan yang tepat untuk mengajarkan pendidikan tersebut. Anak seorang murid taman kanak-kanak yang diperdengarkan dongeng akan mendengarkannya dengan penuh saksama. Mereka seakan ikut serta dalam cerita tersebut 
yang akan membawa mereka kepada imajinasi yang indah. Sekolah juga merupakan tempat yang efektif untuk bersosialisasi. Anak-anak akan mendapat teman baru. Mereka dapat menjalin interaksi dan belajar hidup bersama-sama di lingkungan sekolahnya. Di dalam sekolah pula, mereka juga berlatih untuk mengembangkan rasa peduli kepada teman apabila diperlukan. Rasa tolong-menolong dan menghargai sesama juga ditanamkan di lingkungan kecil ini. Bagi anak-anak, sekolah tempat mereka belajar juga dirasakan telah menjadi lingkungan yang besar karena mereka baru dikenalkan kepada lingkungan luar. Dengan kata lain, karena sekolah merupakan lingkungan pertama yang dikenalkan kepada anak, maka oleh anak, lingkungan sekolah telah menjadi tempat untuk belajar berbagai pengatahuan yang baru saja dikenalnya.

Sesuai yang diungkapkan oleh Ki Hajar Dewantara, bahwa pendidikan haruslah berpedoman pada istilah Jawa among, ngemong, dan momong ${ }^{7}$, yang artinya menjaga dengan dihibur, jangan sampai yang dijaga merasa bersedih. Dalam pendidikan, guru adalah yang menjaga siswa. Siswa adalah orang yang sedang mencari ilmu, maka ibaratnya mereka sedang bersedih karena belum menemukan apa yang dicari. Maka, guru di sini menjadi penenang dan penghibur dengan cara memberikan ilmu dan mengajarkannya untuk diamalkan dalam kehidupan sehari-hari sehingga mereka, siswa merasa bahagia karena telah menemukan apa yang mereka cari. Mendidik jangan sampai terkesan memaksa, juga tidak sekedar memimpin. Terdapat hiburan agar murid tidak merasa sedang belajar karena kata belajar adalah suatu kondisi yang dikenal menegangkan, diatur, disuruh berbuat ini dan itu. Melalui metode pendidikan karakter yang baik, anak belajar tetapi dengan tidak dirasakannya belajar oleh anak tersebut. Mereka tidak merasa terbebani karena harus menghafal banyak kata untuk diucapkan dengan baik, banyak istilah dari kata kerja untuk dikerjakan dengan sikap yang baik pula, tetapi yang mereka rasakan adalah sedang bermain. Tidak ada perasaan lain dalam bermain kecuali rasa senang dan terhibur. Akan tetapi, karakter yang diselipkan tetap melekat pada jiwa anak sehingga membentuk pribadi mereka agar menjadi baik. Mereka tidak diatur untuk melakukan pekerjaan, tetapi diperintah bertindak baik dengan meniru perilaku baik yang dicontohkan oleh seorang guru maupun orang tuanya. 


\section{Perkembangan Psikologi Anak}

Kata psikologi berasal dari phyche yang artinya ruh, jiwa, atau daya hidup dan logos yang berarti ilmu. Jadi, psikologi artinya ilmu tentang jiwa. Psikologi adalah ilmu yang ingin mempelajari manusia ${ }^{8}$. Menurut Gross psikologi adalah ilmu tentang pikiran dan perilaku. Sedangkan kaitannya dengan perkembangan anak, psikologi berarti ilmu yang mempelajari tentang perkembangan jiwa yang mempengaruhi perilaku pada anak. Perilaku yang dihasilkan dari sikap anak akan membentuk karakter yang akan berlaku sampai dewasa sepanjang tidak ada faktor lain yang mempengaruhi. Dalam usia yang sedang berkembang ini, diharuskan bagi anak untuk mendapatkan pendidikan yang mendorong anak untuk memiliki karakter yang baik. Mereka ditempatkan di lingkungan yang mampu menempatkan mereka pada kondisi tersebut. Lingkungan yang baik menjadi tempat yang tepat untuk seorang anak dapat tumbuh dan berkembang dalam setiap tahap hidupnya sehingga karakter atau sikap yang diajarkan oleh lingkungannya adalah semua hal yang baik.

Dunia kognitif bagi anak-anak memiliki sifat yang kreatif, bebas, dan penuh imajinasi. Menurut Piaget ${ }^{9}$, anak-anak usia dua sampai tujuh tahun mulai mereprentasikan dunia dengan menggunakan kata-kata, bayangan, dan gambar. Anak-anak memperoleh kemampuan untuk membayangkan penampilan objek yang tidak hadir secara fisik. Mereka mulai menggambarkan apa yang ada dalam imajinasinya dalam bentuk coretan, seperti menggambar lingkaran, segitiga, gunung, rumah, dan sebagainya dalam bentuk coretan tidak teratur. Dari apa yang mereka dengar, mereka lihat, dan yang mereka rasakan akan digambarkan melalui coretan sehingga menjadi pengetahuan baru dan kreativitas baru bagi mereka mengenai bentuk dari sebuah sesuatu dan mulai dengan permainan pura-pura seperti masak-masakan, motor-motoran, dan semua permainan dalam imajinasi mereka. Tidak jarang pula mereka menggambar sesuatu yang terdapat pada khayalannya dan menamai gambar tersebut sesuai keinginannya. Sesuai perkembangan umurnya, mereka dapat mengkombinasikan gambar tersebut dengan warna yang dicoret-coret dan masih tidak teratur. Lama kelamaan, warna tersebut menjadi teratur dan rapi sepanjang mereka rajin melakukan latihan-latihan.

Perkembangan selanjutnya, anak-anak mulai berpikir menggunakan penalaran primitif dan mulai ingin mengetahui jawaban dari sebuah pertanyaan yang akan mereka ajukan. Mereka membuat orang dewasa merasa kesal karena terus-menerus mengajukan pertanyaan karena 
keingintahuannya. Mereka ingin mengetahui mengapa daun dapat jatuh, matahari dapat bersinar, air tidak dapat digenggam, dan lain-lain disertai dengan alasan dan penjelasannya. Pertanyaan seperti ini mendorong anak untuk cerdas karena melatih berpikir yang kritis dan mengembangkan daya imajinasinya dengan menebak-nebak jawaban dari pertanyaan mereka tersebut sambil menunggu jawaban pastinya. Oleh karena itu, anak-anak kadang menjawab sendiri pertanyaan yang mereka ajukan kemudian orang tua harus meluruskan pengetahuan baru anak tersebut. Pada akhirnya, anak-anak memiliki pengetahuan yang luas seiring dengan perkembangan usianya dan rasa ingin tahunya tesebut.

\section{Dongeng}

Terdapat banyak pengertian dongeng. Dongeng adalah segala bentuk narasi, baik itu tertulis atau oral, yang sudah ada dari tahun ke tahun ${ }^{10}$. Jadi, dongeng sudah ada sejak zaman dahulu dan diceritakan secara turun temurun untuk mengajarkan nilai moral tertentu kepada anak agar anak dapat meneladani karakter baik yang terkandung di dalamnya. Sedangkan narasi tersebut merupakan khayalan yang tidak masuk akal, tetapi dapat ditarik manfaatnya. Seperti cerita Timun Mas yang ketika biji timun disebar, langsung berubah menjadi hutan yang sangat lebat mengalahkan raksasa. Akan tetapi, alur yang tidak masuk akal tersebut dapat diambil pelajaran baiknya, yaitu jangan menindas kaum lemah dan kita tetap harus membela kebenaran. Adapun dongeng Malin Kundang dapat diambil pelajaran baiknya yaitu sebagai anak harus menghormati dan berbakti kepada orang tua meskipun tidak masuk akal karena seorang manusia dapat secara langsung berubah menjadi batu. Sama halnya dengan kisah yang selalu pandai dan dapat mengalahkan siapapun, termasuk harimau dan singa yang hendak memangsanya. Dengan kecerdikannya, kancil dapat lolos dari kebuasan binatang-binatang dalam hutan yang ia tempati. Begitu juga dengan binatang-binatang lain yang selalu meminta bantuan kepada kancil, kancil selalu dapat mengatasi masalah teman-temannya tersebut. Dalam kehidupan sehari-hari, jarang sekali ditemukan orang yang demikian. Akan tetapi, cerita kancil yang pandai dapat diambil pelajarannya yaitu agar anak dilatih untuk bersikap pandai dan tepat dalam memutuskan suatu masalah tanpa adanya kesombongan karena telah menolong semua temannya.

Sedangkan dongeng menurut Carr Lemon dan Cannadine adalah cerita sejarah yang berisi pengalaman tentang kejadian masa lampau dan 
merupakan salah satu sumber sejarah tradisi lisan ${ }^{11}$. Dongeng disampaikan orang tua kepada anak secara lisan dan anak memahami isi dongeng tersebut. Jadi, dongeng berisi tentang masyarakat, sejarah, fenomena alam, serta harapan untuk perubahan. Seperti yang telah disebutkan di atas, bahwa dongeng disampaikan kepada generasi berikutnya secara turun temurun menggunakan lisan dan merupakan suatu kebudayaan yang harus tetap dilestarikan. Oleh orang tua kepada anak maupun oleh guru kepada murid. Cerita dalam dongeng biasanya terasa indah karena tentang kejahatan yang dilawan dengan kebaikan dan pada akhirnya kebaikanlah yang akan menang.

Menurut Einon dongeng adalah cerita yang berisi kisah-kisah menakutkan seperti ibu tiri yang jahat, anak-anak yang dipanggang dalam oven, dan serigala yang buas ${ }^{12}$. Meski demikian, cerita-cerita tersebut disukai banyak anak karena memberikan kesempatan anak-anak untuk menggambarkannya ke dalam khayalan mereka.

Dengan demikian, dapat disimpulkan bahwa dongeng merupakan cerita yang dikarang dengan penuh keindahan yang tidak masuk akal, yang disampaikan kepada generasi setelahnya dengan cara lisan, berkisah kebaikan yang melawan kejahatan, dan biasnya berisi tentang masyarakat, sejarah, fenomena alam, dan perjuangan terhadap harapan yang ingin diwujudkan dan mengandung pesan moral yang sangat berharga bagi perkembangan karakter dan kondisi jiwa anak.

\section{E. Manfaat Dongeng}

Dongeng merupakan sebuah karya sastra, yaitu sastra anak. Menurut Rohinah M. Noor, kata sastra berasal dari bahasa Sansekerta yang artinya tulisan atau karangan. Karangan yang dimaksud ditulis dengan bahasa yang indah dan isi yang baik ${ }^{13}$. Sedangkan sastra anak adalah citraan dan atau metafora kehidupan yang disampaikan kepada anak yang melibatkan baik aspek emosi, perasaan, pikiran, syaraf sensori, maupun karangan moral yang diekspresikan dalam bentuk-bentuk kebahasaan yang dapat dijangkau dan dipahami oleh pembaca anak-anak ${ }^{14}$. Dengan demikian, dongeng dikarang memiliki tujuan, yaitu merangsang perkembangan sensori anak agar otak semakin berkembang yang selanjutnya akan melibatkan motorik anak berkembang dengan baik, yaitu syaraf-syaraf pergerakan dapat berfungsi dengan baik. mengajarkan sastra sejak dini kepada anak, akan akan terasah kepekaan atau sensibilitasnya, kehalusan, dan imajinasi yang berkaitan erat dengan pembangunan karakter luhur. 
Dongeng memberi pembelajarang khusus bagi anak agar dapat berekspresi seperti yang ditunjukkan dalam isi dongeng yang didengar.

Nilai-nilai dalam karya sastra, dalam hal ini dongeng, tidak disampaikan secara langsung, tetapi melalui cerita dan metafora-metafora sehingga proses pendidikan berlangsung menyenangkan dan tidak menggurui, secara tidak sadar merekonstruksi sikap dan kepribadian anak ${ }^{15}$. Karena anak tidak merasa digurui, anak tidak terkekang dan merasa tegang karena harus belajar ini dan itu. Anak-anak lebih menikmati proses pembelajaran yang tanpa terasa belajar, tetapi dengan cara bermain. Cara belajar ini lebih efektif bagi anak di usia kanak-kanak karena pada usia ini, anak-anak sedang mengeksplorasi dunia yang baru saja dikenalnya. Karena baru pertama kali, cara yang mereka butuhkan yaitu dengan cara yang tidak memberatkan dan membuat mereka tidak nyaman. Cara yang menyenangkan yaitu dengan cara bermain.

Dongeng sangat disukai anak karena memberikan kesempatan anak untuk berimajinasi dengan menggambarkan peristiwa-peristiwa yang terdapat di dalam dongeng ke dalam khayalannya. Dengan demikian, sastra dongeng dapat merangsang kreativitas anak untuk berpikir kritis melalui rasa penasaran akan jalan cerita dan metafora-metafora. Sebelum mengetahui kelanjutan cerita dan akhir dari cerita itu seperti apa, anak mulai menebak sesuai daya khayalnya. Bahkan, anak akan menciptakan cerita dongeng sendiri sehingga melatih kreativitas berpikir dan menceritakannya kepada temannya. Hal ini akan melatih keberanian berbicara dengan orang lain. Selain itu, juga melatih anak untuk merangkai kata dengan baik dan benar karena kecerdasan seseorang juga ditentukan dari bagaimana ia berbicara dan menyusun kata sehingga mudah dipahami banyak orang. Apabila sejak kecil mereka sudah berani berbicara, kemungkinan di waktu dewasa juga tidak jauh dari itu, bahkan lebih baik.

Selain manfaat yang telah disebutkan di atas, dongeng juga dapat mengajak anak untuk gemar membaca buku. Di zaman yang serba digital, banyak orang, bahkan anak kecil sudah mengenal telepon genggam. Dalam kesehariannya, seseorang jarang sekali lepas dari telepon genggam di tangannya. Karena sifatnya yang multi fungsi, telepon genggam juga telah mampu mengubah buku cetak menjadi buku digital (e-book). Akan tetapi, kecanggihan ini tidak baik untuk kesehatan mata dan syaraf otak karena cahaya dari layar telepon genggam tersebut memang tidaklah baik dan otot-otot leher dipaksa untuk tegang selama di depan layar tersebut. Oleh karena itu, peran buku seharusnya tetap menjadi penting di setiap orang, termasuk anak-anak. Dengan dibiasakan dibacakan dongeng, anak- 
anak akan tertarik dan kecanduan dengan dongeng sehingga suatu saat anak akan meminta untuk tidak dibacakan lagi, melainkan membacanya sendiri. Apabila hal ini dilakukan secara rutin, dapat menjadikan anak gemar membaca sampai mereka dewasa. Karena orang sukses dapat dilihat dari seberapa banyak buku yang telah mereka baca.

Dengan membaca dongeng, anak-anak pun menjadi lebih pandai karena selain dapat membedakan hal yang baik maupun yang buruk, juga dapat mengambil pelajaran berharga tentang sikap dan moral yang baik untuk diterapkan dalam kehidupan sehari-hari. Mereka mempunyai banyak kosakata yang dapat digunakan untuk variasi kata dalam berbicara atau bercerita karena daya ingatnya pun menjadi lebih tajam. Cara berbicara anak berkembang sesuai dengan kesan-kesan pendengaran dan pengamatan yang diterima anak melalui dongeng. Anak-anak juga menjadi lebih tenang karena perasaanya telah dilatih pada saat mencermati alur dan setiap permasalahan dalam dongeng. Mereka juga lebih terbuka dengan hal-hal yang menimpa dirinya. Mereka tidak akan merasa dirinya dikekang karena mampu mengutarakan pendapat apabila keputusan orang tuanya tidak sesuai dengan pendapatnya. Pikirannya juga lebih seimbang, artinya akan lebih menjadi penurut.

Berdasarkan penelitian para $a$ hli $^{16}$, hal yang berhubungan dengan sastra, termasuk dongeng itu sendiri adalah hasil dari kerja otak kanan. Sedangkan otak kanan sangat baik dalam mengolah informasi, menentukan kesuksesan seseorang di masa yang akan datang lebih banyak dari otak kiri, lebih kreatif, inovatif, intuisi, jujur, ulet, tanggung jawab, disiplin, etika yang baik, simpati, dan empati. Dengan demikian, semakin anak diajarkan sastra, dalam hal ini dongeng, akan melatih otak kanan untuk bekerja lebih optimal. Otak kanan lebih peka dengan hal-hal yang berhubungan dengan etika dan moral. Semakin baik kerja otak kanan seseorang, maka semakin baik ia dalam bertindak di kehidupan sehari-harinya. Selain itu, otak kanan memiliki kapasitas penyimpanan ingatan yang lebih besar sepuluh ribu kali dari otak kiri. Akan menjadi lebih baik seseorang yang otak kanannya berfungsi baik.

Dari uraian di atas, dapat disimpulkan bahwa manfaat dongeng antara lain untuk mengajarkan nilai moral yang baik, mengambangkan daya imajinasi, menambah wawasan, meningkatkan kreativitas, mendekatkan hubungan anak dengan orang tua atau guru, membangun mental, mengajarkan anak merangkai kata, melatih kemampuan berbahasa, mendorong anak mencintai buku, melatih anak berpikir sistematis, dan menghilangkan ketegangan. Begitu banyaknya manfaat pada anak apabila 
mereka masih deperdengarkan dongeng, maka para orang tua sebagai pendidik pertama diharapkan masih dapat melakukannya di setiap hari. Begitu juga dengan guru untuk melakukannya setiap pembelajaran berlangsung, karena metode belajar yang tepat akan lebih efektif. Sastra yang telah diajarkan sejak dini, anak-anak akan terasah kepekaan atau sensibilitasnya, kehalusan, dan imajinasi yang berkaitan erat dengan pembangunan karakter luhur.

\section{F. Dongeng Burung Merpati dan Semut Merah}

Pada suatu hari, seekor burung merpati melihat ada seekor semut sedang berjuang supaya tidak tenggelam di atas sungai. Lalu merpati itu tak hanya diam saja. Ia segera memetik sehelai daun di atas pohon dan dijatuhkannya di atas sungai.

"Mut, cepat kau berenang dan naiklah ke atas daun !" teriak merpati.

Semut lantas berenang menuju sehelai daun dan naik di atasnya. Semut akhirnya selamat tidak tenggelam di sungai.

Beberapa hari berikutnya seekor semut tadi melihat burung merpati sedang terbang dan hinggap di atas ranting pohon. Ada seorang pemburu binatang sedang mengarahkan senapannya ke arah burung merpati. Si semut ingin menyelamatkan burung merpati, lalu ia menggigit kaki si pemburu binatang. Pemburu kesakitan dan senapannya menembak melesat jauh dari burung merpati. Akhirnya burung merpati selamat dari bidikan pemburu. Burung merpati pun terbang dan berucap, “Terima kasih ya semuutt...kau telah menyelamatkan nyawaku !"

Semut pun berucap dalam hati, "Terima kasih kembali ....kemarin kau juga telah menyelamatkan nyawaku."17

\section{G. Analisis Pendidikan Karakter dalam Dongeng Burung Merpati dan Semut Merah}

Dalam dongeng "Burung Merpati dan Semut Merah", diceritakan bahwa burung merpati menolong semut yang hampir tenggelam di danau dengan menjatuhkan daun sehingga semut dapat menaikki daun tersebut dan akhirnya semut selamat dan kembali ke daratan. Dalam kutipan cerita tersebut, terdapat karakter yang harus diteladani, yaitu rasa peduli dan saling menolong kepada sesama. Anak-anak dapat menjadikan teladan untuk menolong temannya di waktu kesusahan. Selain itu, rasa empati untuk turut mengatasi masalah orang lain juga harus diteladani dari 
karakter yang telah digambarkan. Anak-anak dapat menirunya dalam lingkungan tempat mereka tinggal. Misalnya, ketika di rumah mereka menjumpai ibunya sedang kerepotan melipat pakaian, maka anak akan terdorong untuk membantu, meskipun hasilnya tidak rapi. Atau di sekolah ketika melihat temannya jatuh, ia dengan tanggap membantu temannya tersebut untuk berdiri. Mereka dilatih mempunyai sikap peduli dan tidak hanya mempedulikan dirinya sendiri. Mereka cepat tanggap terhadap keadaan lingkungan sekitar.

Kutipan dongeng di atas masih terdapat cerita kelanjutannya yaitu suatu ketika semut yang pernah ditolong oleh burung merpati, kini keadaan berbalik. Semut melihat pemburu sedang membidikkan peluru kepada burung merpati yang sedang bertengger di atas pohon. Semut mengetahui bahwa pemburu hendak menembak burung merpati tersebut, maka dengan cepat semut menggigit kaki pemburu sehingga pemburu kesakitan dan menolong kakinya yang digigit semut tersebut. Akhirnya, burung merpati dapat terbang bebas, tidak menjadi bahan incaran sang pemburu. Dari kutipan tersebut, semut memiliki karakter untuk membalas kebaikan burung merpati yang pernah menolongnya, selain sikap menolong sesama. Seorang penolong tidak mengharap kembalian dari apa yang telah ia berikan. Akan tetapi, karena merasa pernah ditolong, maka orang tersebut sebaiknya memiliki kesadaran tersendiri untuk membalas kebaikan penolongnya dengan kebaikan pula. Karakter untuk memiliki kesadaran membalas kebaikan orang telah diajarkan dalam dongeng tersebut. Selain karena untuk membalas kebaikan penolongnya di waktu yang lalu, maka sikap peduli dan saling menolong juga diajarkan pada kutipan dongeng yang kedua tersebut.

Demikian juga dalam ajaran agama Islam terdapat perintah untuk menjalin hubungan baik dengan orang lain karena kita tidak dapat hidup sendiri yang pasti di kemudian hari juga membutuhkan bantuan orang lain. Dalam dongeng di atas, burung merpati menolong semut dengan ikhlas tanpa rasa pamrih karena ia tidak mengetahui apa yang akan terjadi di kemudian hari. Dari hal tersebut dapat dipahami bahwa kita harus memiliki rasa belas kasih terhadap sesama dan tidak enggan untuk menolong saudara kita yang sedang kesusahan tanpa ada rasa pamrih atau mengaharap balasan. Akan tetapi, keesokan harinya, ia pun hampir mendapat bencana, yaitu hampir ditembak oleh pemburu. Semut yang mengetahui akan apa yang akan terjadi pada burung merpati, maka dengan cepat ia menggigit sang pemburu suapaya pemburu kesakitan dan tidak jadi menembak burung merpati yang saat itu sedang bertengger di 
atas pohon. Tokoh semut mengajarakan kita untuk peduli dan menolong, terlebih karena ia pernah ditolong oleh burung merpati. Semut mempunyai rasa ingin membalas budi kepada burung merpati. Dengan demikian, berarti semut telah mengajarkan pentingnya memiliki rasa ingin berbalas budi.

Dari dongengyang telah diuraikan di atas, karakter luhuryang diajarkan yaitu melatih anak untuk memiliki rasa peduli, ikhlas, rasa belas kasih, empati, tolong menolong, berterima kasih, dan membalas kebaikan orang lain dengan kebaikan pula. Dapat diajarkan kepada anak bahwa kita harus saling menolong apabila terdapat teman yang mebutuhkan pertolongan karena kita tidak pernah mengetahui apa yang akan terjadi menimpa kita di lain waktu. Barangkali kita juga membutuhkan pertolongan. Sebagai orang yang pernah ditolong, juga harus memiliki kesadaran untuk peduli dan membalas dengan kebaikan. Karakter tersebut mampu diajarkan kepada anak tanpa harus menggurui dengan memberitahu dan menyuruh anak untuk berbuat demikian. Biasanya, seorang anak akan melakukan perintah seperti melakukan larangan. Mereka akan bertindak berkebalikan dari apa yang seharusnya mereka lakukan. Dengan metode dongeng, mereka akan melakukan dengan ikhlas karena tidak disuruh, melainkan keinginannya untuk berbuat seperti tokoh idola di dalam dongeng.

\section{H. Relevansi Dongeng Burung Merpati dan Semut Merah terhadap Perkembangan Psikologi Anak}

Terdapat banyak karakter luhur yang dapat diteladani dari dongeng Burung Merpati dan Semut Merah di atas, di antaranya rasa peduli, empati, tolong menolong, berterima kasih, dan membalas kebaikan orang lain dengan kebaikan pula. Dalam teori tentang perkembangan bahwa apa yang anak-anak dengar, lihat, dan rasakan dapat mempengaruhi kognitif mereka. Apabila pengetahuan mereka meningkat, artinya perkembangan otak mereka baik dan akan berpengaruh terhadap kondisi jiwanya yang pasti baik. Anak-anak dapat menerapkan sikap suka menolong temannya, maka dipastikan kondisi jiwanya pun sehat. Mereka yang mempunyai sikap peduli terhadap sesama akan dipastikan karena mereka memiliki kepribadian yang baik dan psikologi atau keadaan jiwa mereka adalah baik.

Dongeng, menurut Huck, Hepler, dan Hickman (1987) dapat diklasifikasikan menjadi dua jenis, yaitu dongeng tradisional dan dongeng fantasi modern ${ }^{18}$. Dongeng tradisional adalah cerita yang sebarkan dari 
mulut ke mulut, turun-temurun dari generasi ke generasi berikutnya dan tidak jelas pengarangnya. Ceritanya bersumber dari pengalaman para leluhur atau cerita yang tertulis dalam kitab suci. Dongeng ini biasanya mengkisahkan tentang kancil mencuri timun yang mengajari kejujuran, kisah burung elang dan ayam yang mengajari larangan berbuat serakah, dan sebagainya. Hal demikian dapat mempengaruhi kondisi jiwanya sehingga menjadi lebih baik. Sedangkan dongeng fantasi modern merupakan kompilasi dari berbagai dongeng tradisional dan memiliki pengarang yang jelas. Cerita ini bersumber dari imajinasi pengarang sesuai keadaan pada masa itu sehingga memiliki alur cerita yang lebih menarik bagi penikmat dongeng, yaitu anak-anak. Pelopor dongeng fantasi modern adalah Hans Christian Andersen, dan beberapa karyanya berjudul Thumbellina dan The Ugly Duckling (1987). Biasanya, dongeng modern mengkisahkan tentang perjuangan membela kebenaran dan ini melatih kepribadian anak untuk membedakan mana yang baik dan yang buruk.

\section{Proses Mendongeng}

Untuk menceritakan sebuah dongeng kepada anak, dapat dilakukan dengan dua cara yang dikemukakan oleh Ralibi pada tahun 2008, yaitu mendongeng menggunakan alat peraga dan mendongeng tanpa menggunakan alat paraga ${ }^{19}$. Mendongeng dengan alat peraga dapat dilakukan dengan alat-alat peraga yang menunjang dongeng tersebut disampaikan. Misalnya boneka tangan, buku cerita, dan lain sebagainya. Mendongeng dengan cara demikian dapat membantu mempercepat daya imajinasi anak. Sedangkan dongeng tanpa alat peraga adalah mendongeng yang hanya menggunakan mimik, ekspresi, intonasi, dan suara-suara yang ditirukan untuk mengikuti suara asli yang diceritakan. Dengan cara ini anak-anak belajar mengartikan suatu perasaan dari mimik dan gerak muka, sehingga suatu saat nanti dapat menjadi pendongeng yang baik. Dengan demikian, dongeng dapat menarik perhatian anak dengan mudah karena benda-benda dengan warna yang menarik banyak disukai anak.

Sedangkan dalam mendongeng itu sendiri, terdapat hal-hal yang harus diperhatikan menurut Al Qudsy dan Nurhidayah (2010) ${ }^{20}$, di antaranya cerita harus berurutan sesuai tahapan perkembangan anak. Hal ini dimaksudkan agar cerita mudah dipahami oleh anak. Dongeng harus mengandung unsur nilai-nilai pendidikan dan hiburan karena ini memang untuk tujuan pembelajaran. Adapun bagi pendongeng harus mengusahakan agar selalu tercipta suasana gembira dengan bahasa yang sederhana sesuai 
tingkat pengetahuan anak. Pendongeng harus menghayati isi cerita yang dibawakan dan meresapi seluruh bagian dari cerita yang didongengkan dan selalu mengamati perkembangan reaksi emosi pada diri anak untuk mempertahankan kesan yang menyenangkan sehingga anak tidak merasa bosan. Kata-kata yang diucapkan pendongeng harus jelas dan melibatkan anak secara aktif untuk melatih keberanian anak. Pendongeng juga harus merahasiakan jalan cerita agar anak terpusat pada adegan dan durasinya disesuaikan dengan situasi dan kemampuan anak dalam mendengarkan, jangan sampai anak merasa bosan karena jalan cerita yang monoton.

\section{Kesimpulan}

Akhir-akhir ini dengan banyaknya kasus yang menunjukkan bahwa nilai moral bangsa ini merosot, maka dengan gencar, kita harus melakukan perubahan yang terjadi sekarang ini. Dengan dilakukannya pengajaran tentang karakter yang baik bagi anak sejak dini, dapat menurunkan jumlah kasus yang demikian. Pengajaran karakter baik dapat melalui pembacaan dongeng kepada anak yang telah menjadi kebiasaan masyarakat Indonesia sejak zaman dahulu.

Indonesia dikenal sebagai bangsa yang ramah dan memiliki banyak kebudayaan. Salah satu contoh kebiasaan yang telah menjadi budaya adalah orang tua yang memperdengarkan dongeng kepada anaknya menjelang tidur. Hal tersebut dilakukan karena dongeng memiliki banyak pengaruh terhadap anak. Pendidikan yang mengajarkan karakter baik dan perbedaannya dengan karakter buruk dapat melalui dongeng dengan tokoh-tokohnya. Pengamalan karakter yang diteladankan dari tokoh di dalam dongeng juga dapat mempengaruhi kondisi perkembangan jiwanya sehingga anak memiliki jiwa yang tenang, perasaan yang halus, budi pekerti yang baik, dan kondisi jiwa yang baik lainnya sehingga memberi pelatihan kepada mereka mental yang baik untuk menjalani kehidupannya di masa yang akan datang. Salah satu dongeng yang mengajarkan moral yang baik adalah dongeng yang berjudul "Burung Merpati dan Semut Merah".

Beberapa nilai karakter yang diajarkan dalam dongeng "Burung Merpati dan Semut Merah" adalah rasa belas kasih terhadap sesama, saling menolong, peduli, ikhlas, empati, berterima kasih, dan membalas kebaikan orang lain dengan kebaikan pula. Nilai-nilai tersebut sejalan dengan ajaran agama Islam sebagai pedoman kita untuk hidup bermasyarakat. Dongeng ini disajikan dengan cerita yang menarik sehingga dapat menarik perhatian 
anak dan disukai banyak anak. Alur cerita yang runtut sehingga mudah dipahami dan anak mudah meneladani dalam kehidupan sehari-hari.

\section{Endnotes}

1 Lembaga Kajian dan Pemberdayaan Mahasiswa IAIN Purwokerto, "Jurnal Ilmiah Mahasiswa Raushan Fikr", Vol. 7 (Purwokerto: Lembaga Kajian dan Pemberdayaan Mahasiswa IAIN Purwokerto, 2018), h. 134.

2 Moh. Haitami Salim dan Syamsul Kurniawan via Syamsul Kurniawan, "Pendidikan Karakter Konsepsi dan Implementasinya Secara Terpadu di Lingkungan Keluarga, Sekolah, Perguruan Tinggi, dan Masyarakat", (Yogyakarta: Ar-Ruzz Media, 2013), h. 26.

3 Abu Ahmadi dan Nur Ukhbiyati via Syamsul Kurniawan,... h. 27.

4 Departemen Pendidikan Nasional KBBI, via Syamsul Kurniawan,... h. 28.

5 Agus Wibowo via Syamsul Kurniawan,... h. 31

6 Lickona via Tutuk Ningsih, "Implementasi Pendidikan Karakter", (Purwokerto: STAIN Press, 2014), h. 22.

7 Tutuk Ningsih,... h. 27.

8 Woodworth dan Marquis via M. Ngalim Purwanto, "Psikologi Pendidikan", (Bandung: PT Remaja Rosdakarya, 1984), h. 1.

9 John W. Santrock, "Life-Span Development Perkembangan Masa-Hidup", (Penerbit Erlangga, 2011), h. 248-250.

10 Menurut Huck, Hepler, dan Hickman via jurnal Pupung Puspa Ardini, "Pengaruh Dongeng dan Komunikasi Terhadap Perkembangan Moral Anak Usia 7-8 Tahun", h. 46.

11 Carr Lemon dan Cannadine via jurnal Pupung Puspa Ardini,...

12 Einon via jurnal Pupung Puspa Ardini,... h. 47.

13 Rohinah M. Noor, "Pendidikan Karakter Berbasis Sastra Solusi Pendidikan Moral yang Efektif”, (Yogyakarta: Ar-Ruzz Media, 2011), h. 17.

14 Rohinah M. Noor,... h. 37.

15 Rohinah M. Noor, ... h. 38.

16 Hendri, "Pendidikan Karakter Berbasis Dongeng", (Bandung: Simbiosa Rekatama Media, 2013), h. 48-49.

17 https://www.kompasiana.com

18 Huck, Hepler, dan Hickman via jurnal Pupung Puspa Ardini,... h. 48.

19 Ralibi via jurnal Pupung Puspa Ardini,... h. 47.

20 Al Qudsy dan Nurhidayah via jurnal Pupung Puspa Ardini, ,.. h. 47.

\section{DAFTAR PUSTAKA}

Lembaga Kajian dan Pemberdayaan Mahasiswa IAIN Purwokerto. 2018. Jurnal Ilmiah Mahasiswa Raushan Fikr. Vol. 7. No. 2. Purwokerto: Lembaga Kajian dan Pemberdayaan Mahasiswa IAIN Purwokerto.

Pupung Puspa Ardini. Dongeng dan Komunikasi Terhadap Perkembangan Moral Anak Usia 7-8 Tahun. H. 46. 
Kurniawan, Syamsul. 2013. Konsepsi dan Implementasinya Secara Terpadu di Lingkungan Keluarga, Sekolah, Perguruan Tinggi, dan Masyarakat. Yogyakarta: Ar-Ruzz Media.

Purwanto, M. Ngalim. 1984. Psikologi Pendidikan . Bandung: PT Remaja Rosdakarya.

Ningsih, Tutuk. 2014. Implementasi Pendidikan Karakter. Purwokerto: STAIN Press.

Wiyani, Novan Ardy. 2018. Pendidikan Karakter Anak Konsep dan Implementasinya di SD dan MI. Purwokerto: STAIN Press.

Noor, Rohinah M. 2011. Pendidikan Karakter Berbasis Sastra Solusi Pendidikan Moral yang Efektif. Yogyakarta: Ar-Ruzz Media.

Wibowo, Agus. 2013. Pendidikan Karakter Berbasis Sastra Internalisasi Nilai-Nilai Karakter Melalui Pengajaran Sastra. Yogyakarta: Pustaka Pelajar.

Hendri. 2013. Pendidikan Karakter Berbasis Dongeng. Bandung: Simbiosa 